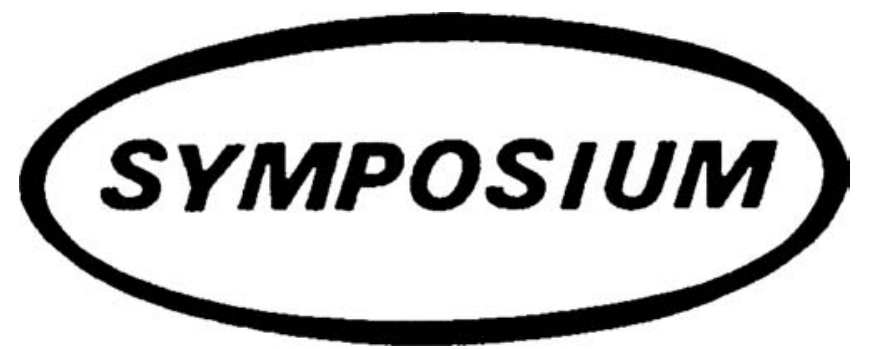

\title{
Re-framing the Geography Dissertation: A Consideration of Alternative, Innovative and Creative Approaches
}

\author{
JENNIFER HILL*, PAULINE KNEALE***, DAWN NICHOLSON ${ }^{\dagger}$, \\ SHELAGH WADDINGTON ${ }^{\ddagger} \&$ WAVERLY RAY ${ }^{\wedge}$ \\ *Department of Geography and Environmental Management, University of West of England, UK, **Higher \\ Education Subject Centre for Geography, Earth and Environmental Sciences, University of Plymouth, England, \\ UK, ${ }^{\dagger}$ Department of Environmental and Geographical Sciences, Manchester Metropolitan University, UK, \\ ${ }^{\ddagger}$ Department of Geography, National University of Ireland, Ireland, ^ Department of Geography, \\ Texas State University - San Marcos, CA, USA
}

ABSTRACT This paper reviews the opportunities and challenges for re-framing the purpose, process, product and assessment of final-year geography dissertations. It argues that the academic centralities of critical thinking, analysis, evaluation, effective communication and independence must be retained, but that the traditional format limits creativity and innovation. Re-imagining capstone projects has implications for students, faculty, departments and institutions, but greater diversity could enhance its relevance to students and employers, better aligning the student experience with the academic interests and future career demands of the 21st century graduate.

KEY Words: Dissertation, capstone project, creativity, innovation, assessment

\section{Context}

The final year of many degree programmes, internationally, involves some form of capstone project. In UK and Irish Honours programmes, the traditionally recognized format is an individual research activity assessed by a written dissertation of 8000-12 000 words (Nicholson et al., 2010). This dissertation should enable students to demonstrate competence in a range of subject-based and transferable skills, and Honours-level knowledge and understanding (QAA, 2007; Harrison \& Whalley, 2008), although its effectiveness has been questioned (Greenbank \& Penketh, 2009). It is regarded as an

Correspondence Address: Pauline Kneale, Higher Education Subject Centre for Geography, Earth and Environmental Sciences, University of Plymouth, Buckland House, Drake Circus, Plymouth PL4 8AA, UK. Email: pauline.kneale@plymouth.ac.uk 
indicator of deep learning, independent research and valuable training for further academic study (James, 1998), but is it a relic of a previous academic era?

There is evidence that the dissertation neither encourages students to be stakeholders in university research, nor supports them in becoming, even peripherally, members of disciplinary research communities (Healey \& Jenkins, 2009a). Various studies indicate that undergraduates believe themselves to be recipients of rather than producers of research (Jenkins et al., 1998; Zamorski, 2002; Brew, 2006). While Harrison and Whalley (2008) highlighted a number of positive issues around dissertations, they also reported concerns about a wide range of aspects of the process, noting that: "As a consequence, the quality of the dissertation is often less than it could have been" (Harrison \& Whalley, 2008, p. 407).

Arguably, the final-year dissertation in its UK and Irish form has remained somewhat static while undergraduate programme objectives increasingly emphasize graduate employability, skills mobility and civic responsibility, alongside subject-based knowledge and understanding (Hennemann \& Liefner, 2010). Graduates are expected to demonstrate autonomy, communicate clearly, engender and respond to change, be socially, economically and politically aware of local, national and global issues, and be prepared for portfolio careers (Harvey et al., 1997). Additional pressures come from the rise in dominance of the global knowledge economy, reduced financial support for institutions and rapid advances in information technology (Terenzini \& Pascarella, 1998; Haigh, 2002; Simplicio, 2007; Lynch et al., 2008). We consider that all undergraduate Honours geography students should engage with primary research (Healey \& Jenkins, 2009b), but we argue that higher-level cognitive, affective and inter-personal engagement is unlikely to be successful unless this research is relevant for the student, aligning with their academic and career interests, and is managed effectively under the constraints identified (Jenkins, 2003; Jenkins et al., 2003, 2007; Turner et al., 2008; Healey \& Jenkins, 2009b; Jenkins \& Healey, 2010).

In this paper, we argue that the dissertation process has limited long-term benefits for students individually, and it neither fulfils the broader ambitions of the research-teaching agenda nor the knowledge-transfer agenda of many departments. The authors consider it timely to examine alternative forms of the dissertation, offering the possibility of engaging with different pedagogic processes, student-student and student-supervisor relationships, and final summative products. As such, options are explored, already established in geography and other disciplines, which would present fit-for-purpose, relevant capstone experiences for geography students as alternatives to the traditional student-selected solo research project. The challenge for the geography community is to consider creatively the purpose, process, product and assessment of final-year research projects to align with the aspirations of 21 st century geographers.

\section{Opportunities and Challenges Exemplified}

\section{Changing Purpose?}

A traditional research project prepares the minority of very able students for further academic study. However, for the majority of students of all abilities seeking employment outside higher education (HE), it may not instil the core personal and transferable skills required by many employers. Additionally, Troyer (1993, p. 247, cited in Hovorka, 2009) asks, "What last academic experience can [faculty] provide graduating seniors that will be valuable for citizenship in the human community?" Arguably, the dissertation could function as a broader socializing agent, instilling a sense of self and civic responsibility. 
In addition to disciplinary understanding, a broader range of final-year undergraduate capstone project styles might better inspire and motivate their authors, preparing the students for further study or employment.

This paper does not seek to dilute the rigour of the dissertation product or experience. Concepts that define the rationale and goals of the majority of final-year courses; critical thinking, synthesis, evaluation and self-authorship (the capacity to internally define one's beliefs, identity and social relations sensu Baxter Magolda, 1999, 2009), student ownership, responsibility and engagement must remain central to the experience, with ample opportunity for critical reflection. It is suggested that more relevant and creative opportunities might offer students greater opportunity to engage in meaningful collaboration and to synthesize learning from personal, academic and professional contexts. This paper presents examples of different styles of capstone projects to meet these goals.

\section{Changing Process?}

We have identified eight styles of capstone project for geography, their challenges and opportunities, ranging from the traditional to the more innovative (Table 1).

Evolving the traditional dissertation. The undergraduate geography dissertation in the UK and Ireland is normally assessed by a written report presenting the outcomes of independent research, sometimes with an oral or poster presentation at an interim stage or alongside final submission (Nicholson et al., 2010). Occasionally, outstanding students are encouraged to seek formal publication of their work, possibly jointly authored with their supervisor. Publication of final-year research project work is becoming more common through online student research journals, e.g. Reinvention (Available at http://www 2.warwick.ac.uk/fac/cross_fac/iatl/ejournal/) and The Plymouth Student Scientist (Available at http://www.theplymouthstudentscientist.org.uk/index.php/pss).

Submitting dissertation research as an academic journal paper, rather than in thesis format, adds a layer of academic credibility making the process more authentic (Nicholson, in press). In part, this is because undergraduates become familiar with the styles and foci of journal articles but rarely read a thesis, and shorter word limits focus thoughts and writing. The attractions of publishing include the opportunity to disseminate work to a wider audience, to complete the research cycle, to participate in a 'real-world' research experience, to develop transferable skills and to reward good and innovative research practice (Walkington, 2008; Nicholson, in press). It can also contribute to career-development opportunities, initiate understanding of publication processes (Walkington \& Jenkins, 2008) and improve motivation to perform at the highest level (Charlesworth \& Foster, 1996).

The Boyer Commission (1998) stimulated a plethora of undergraduate research journals in the USA, but there are far fewer examples in the UK and Ireland (see Walkington \& Jenkins, 2008). UK examples include Charlesworth and Foster (1996) who created a student journal for articles from a second-year course in hydrology. Walkington (2008) piloted a national online undergraduate geography journal Geoverse, developed from an in-house e-journal at Oxford Brookes University called Geoversity. More recently, Nicholson (in press) evaluates a simulation of the professional publication process in a final-year field-based module at Manchester Metropolitan University.

Walkington and Jenkins (2008) present a series of strategies to facilitate the publication of undergraduate research, recommending that dissemination is embedded within the 


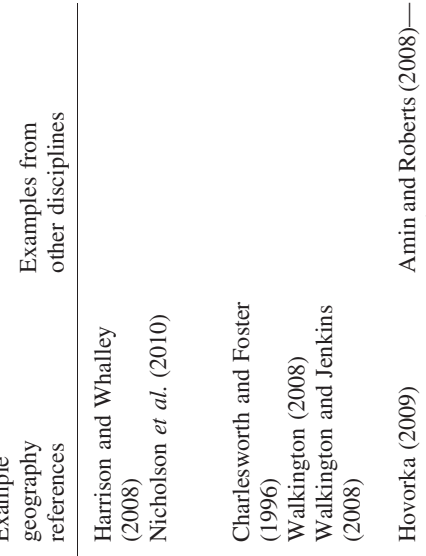
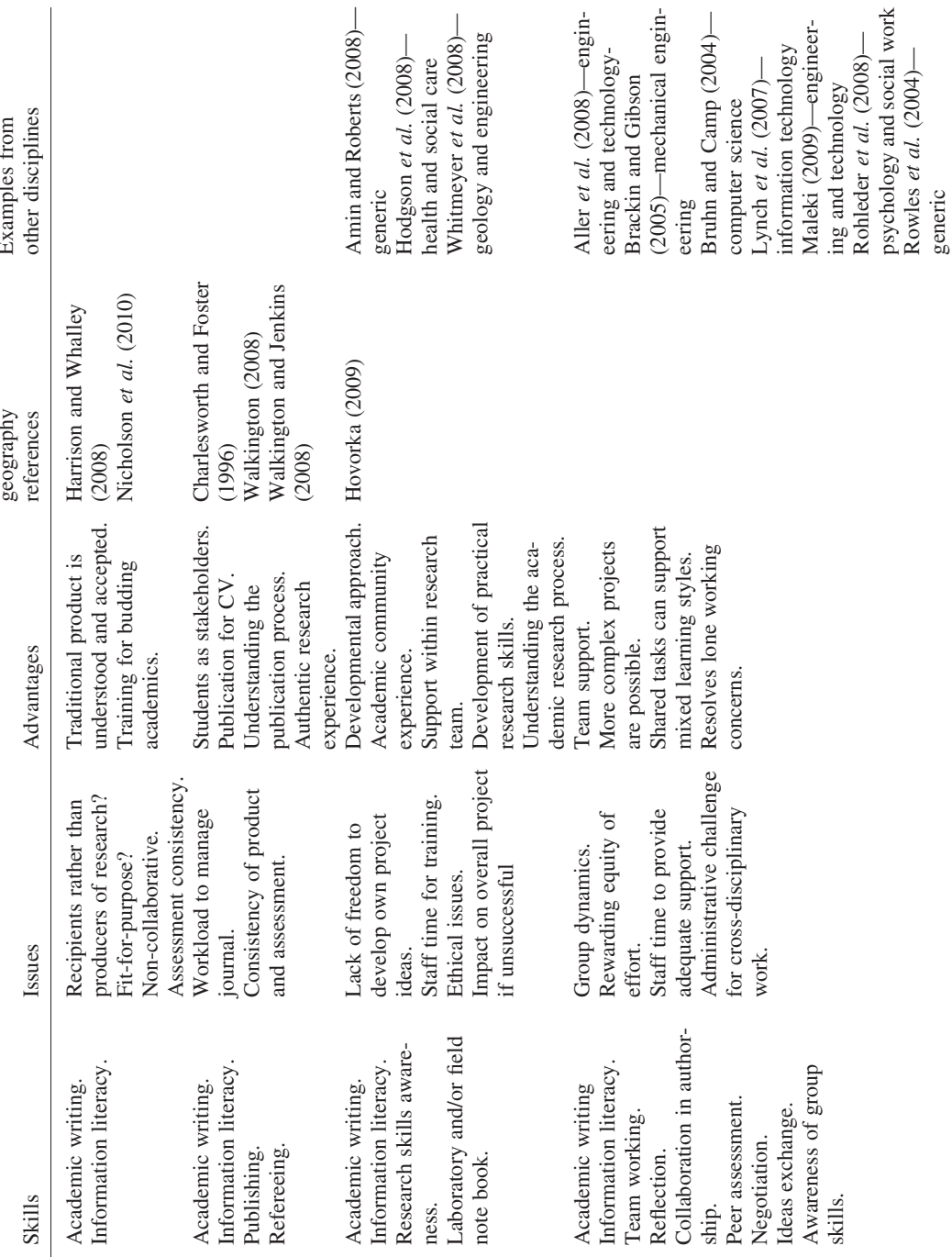

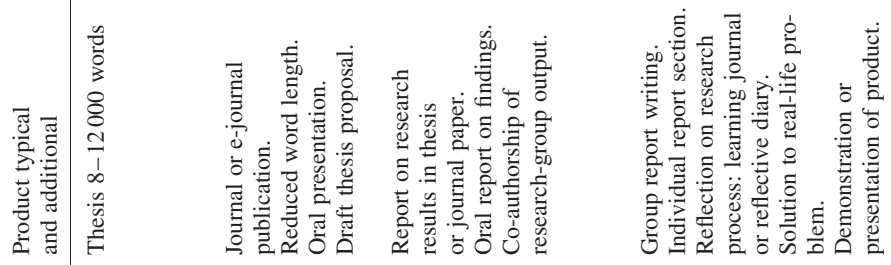
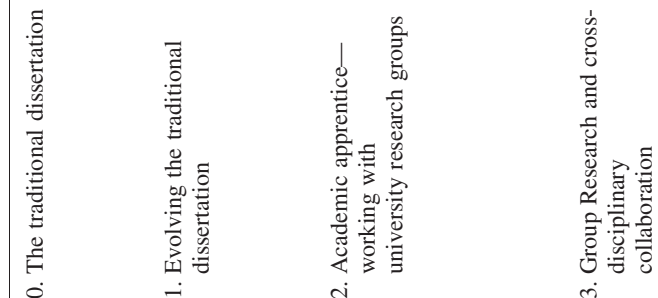


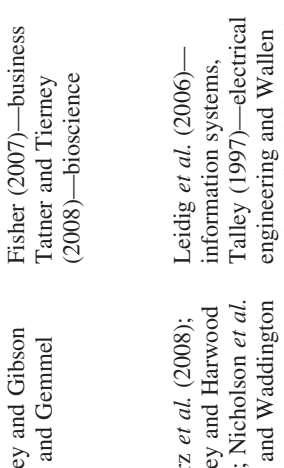

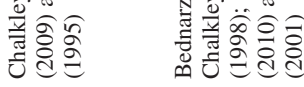

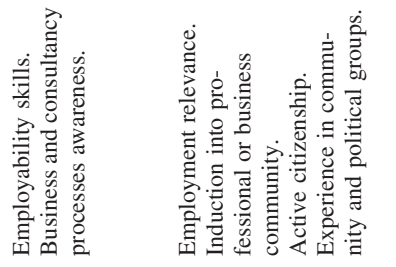

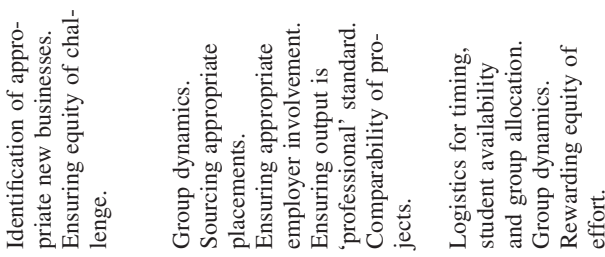

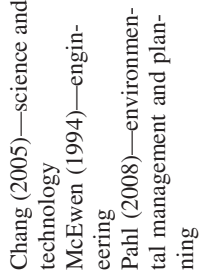

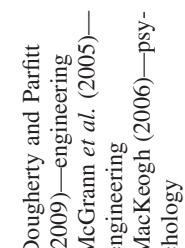

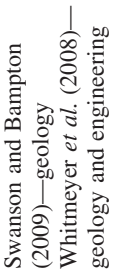

惫
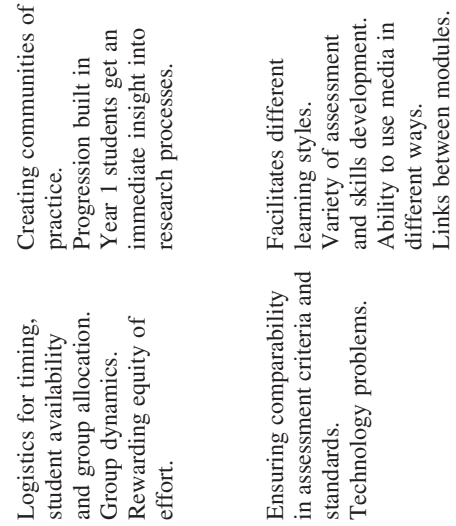

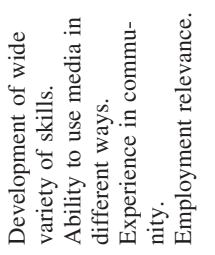

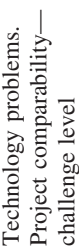

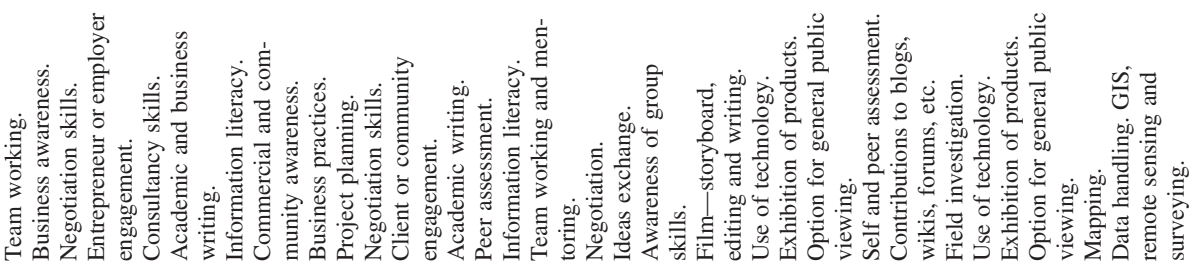

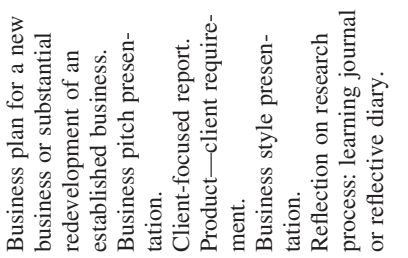

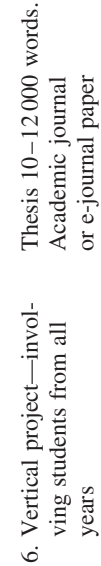

6

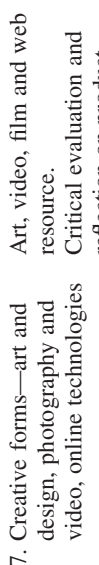

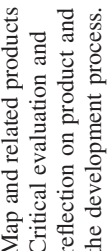

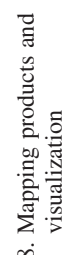


requirements for such projects. Undergraduate research journals could be mainstreamed into assessment, acting as stepping stones to postgraduate research and research careers for academically able and motivated students. Evolving dissertation formats from the thesis to a journal format, with possible e-journal publication, should motivate students to perform at a higher level.

Although there are potential implications for staff workload in managing an undergraduate journal, changing the product to a shorter article may reduce assessment time. There may also be issues relating to product quality and whether inexperienced undergraduates are capable of achieving the standard for 'publication'. However, the success of in-house journals that publish material from all stages of a degree programme (e.g. Geoversity) indicates such difficulties can be overcome by setting appropriate standards and guidelines.

Academic apprentice model-working with university research groups. Most academics work in collaborative research groups. Working in relative isolation with occasional direction from a supervisor does not provide final-year students with a positive introduction to such academic communities of practice (Lave \& Wenger, 1991; Wenger, 1998; Brew, 2003), nor does it introduce them to presenting results in an academic environment (Wagner et al., 2007; Whitmeyer et al., 2008). Amin and Roberts (2008) recognize that there is scope for undergraduate projects to engage students more integrally with research group discussions. These groups create and share knowledge, exchange ideas, collaborate and learn from one another reciprocally through participation (Lave \& Wenger, 1991; Boud et al., 1999).

A cognitive apprenticeship model lays emphasis initially on sharing and passing on what is already known before constructing new knowledge. Students might simply observe and perform basic research tasks in their first year of studies as they learn how the group operates and how they can participate. Subsequently, they might undertake more challenging problem-solving tasks, collaboratively sharing knowledge to enhance performance. There could be an extension to the model found in the physical sciences in the UK, where students often work on projects that are derived from faculty and graduate-student research interests (Stefani et al., 1997). Thus, undergraduates could build collaboratively on the skills they have developed earlier in their studies, they could be integrated into cutting-edge research projects and they could potentially work in more depth than the current dissertation model permits (Rowley \& Slack, 2004). It is important, however, for students undertaking faculty-directed research to be involved centrally in decisions throughout the research process, so that they are realizing desirable learning outcomes, including elements of self-directed learning and decision-making.

Empowering students to become active participants in a research community would encourage relationship building between students and faculty in which undergraduates could be 'co-researchers', jointly constructing knowledge with their supervisors in a negotiated form of independent learning. This aligns with the concepts of students' voices in education (Oldfather, 1995; Fielding, 2001, 2004; Hadfield \& Hawe, 2001; Arnot et al., 2004) and, more particularly, with the concept of radical collegiality, where groups of staff and students are genuinely committed to formulating and solving problems within mutually supportive frameworks of democratic practice (Fielding, 1999). Such partnerships should offer new understandings and insights to faculty and students and should allow students to research more involved and complex issues. This should be more inspiring and motivating, with students gaining a sense of intellectual 
agency and legitimacy. But there are ethical issues in negotiated pedagogies, relating largely to equity and power relationships (Le Heron et al., 2006), for example, the negative connotations inherent in employing students as 'menial' research labourers versus the opportunity for formative collaboration to bring about closer faculty and student engagement (Askins, 2008). There are also issues for supervisors in a relationship, which demand empathy for students as reciprocal co-researchers. Providing a balance between student autonomy and staff support is challenging but essential. There may also be issues relating to the staff time required to provide this support and to the potential effects on the overall project if the student is unable to complete their work. Finally, there are challenges for institutions concerning the requirement to accept students as equal partners in research, developing an 'inclusive emancipatory community' (Fielding, 2001, p. 130).

Group research and cross-disciplinary collaborations. Many US institutions encourage capstone courses that offer experiences beyond the independent research project (Healey \& Jenkins, 2009b). This may involve group work, including external partners, aligning with the collaborative nature of many faculty research projects (Table 1). Hovorka (2009) reported that 43 per cent of departments provided group field courses or internships. Group and cross-discipline projects also mirror organizations where individuals work together, applying differing expertise to a problem and possessing increased capacity and resources over solo researchers to tackle more complex projects (Lynch et al., 2007; Maleki, 2009). English and Computer Technology students at Indiana University-Purdue University, Indianapolis, collaborate on a capstone multimedia project. They are charged with envisioning, developing, presenting and evaluating web-based projects, cross-pollinating one another's learning with their respective disciplinary expertise as the project progresses (Rowles et al., 2004). Rohleder et al. (2008) discuss issues in collaboration across two universities.

It is common practice in engineering disciplines to place students in teams to solve design and development problems from an early stage. Students build relationships with industry and are inspired through practical insights into solving current problems (Dutson et al., 1997; Bruhn \& Camp, 2004; Brackin \& Gibson, 2005). At the College of Engineering, University of Maryland, USA, student teams undertake 4-year, studentinitiated research projects, where they analyse and propose solutions to societal problems, generally involving a significant technology focus (Gemstone, 2010). Team members work as a coordinated group, investigating their project from the perspective of different disciplines, with guidance from a faculty mentor. In the final year, student teams present their research to experts in the field or external agencies and write a team thesis (Healey \& Jenkins, 2009a).

This approach is inspiring for students because they are able to tackle complex problems and address 'live' issues beyond the scope of a solo investigator (Aller et al., 2008). In the context of geography dissertations, group field research could also offer a solution to health and safety concerns around lone working. While such collaborations have obvious potential, it must be acknowledged that implementation may be complex. From an administrative viewpoint, collaboration even within a single discipline can often be challenging — cross-disciplinary and cross-institutional work is likely to pose even more difficulties without considerable time investment by supervisors and a flexible approach within modular structures at institutional level. 
Business aware graduates. Business programmes typically have a business plan dissertation in which students research and present a plan either for a new business or to reinvigorate a current business. In each case, the student gains considerable insight into business processes, strategy and awareness of enterprise and entrepreneurship (Fisher, 2007; Chalkley \& Gibson, 2009).

The capstone Environmental Enterprise Project for the BA in Environment and Business at the University of Leeds asks students to validate an environmental enterprise idea, and to develop a detailed action plan to take it to market, demonstrating how to develop an environmental innovation idea into a feasible enterprise. The assessment is primarily based on a report and the presentation of the plan to a hypothetical investment panel, which includes an entrepreneurial mentor and a venture capitalist.

Students of geography may engage in business and enterprise through the sustainability entrepreneurship concept: "Sustainability entrepreneurship is interdisciplinary by nature, drawing on knowledge from a range of research areas, including conventional entrepreneurship studies, business and environment studies, and newer research into environmental and social entrepreneurship" (Tilley \& Parrish, 2009, p. 5). This work might be undertaken in the context of the Education for Sustainable Development agenda (e.g. Higgitt, 2006), directly linking business awareness with the elements of environmental geography.

Projects that mirror or simulate consultancy processes introduce students to relevant professional business practices and teach them about the nature of collaborative working. At the University of Aberdeen, Scotland, the final-year course in Applied and Engineering Geomorphology involves a group simulation requiring classroom, field and library work (Gemmel, 1995). Student teams work together to prepare a proposal and compete to 'win' a tender from the client assessors. Thus, proposals are evaluated against the assessment criteria and against each other. This simulates the real-world situation in which companies enter into tender competitions to win a contract, a process that all students could benefit from experiencing. One time-consuming issue with such projects is likely to be the need to source appropriate projects on an on-going basis as the work requires an appropriate level of challenge within a genuine (or at least authentic) scenario.

Workplace, service learning and charity sector projects. Dorsey (2001) explored issues around service learning to link undergraduates and faculty with local community members and professionals, such as planners, to tackle community projects (Table 1). Work-based individual and collaborative projects are well established in a range of HE institutions, such as the Work-Place Cooperative Project at the University of Leeds (Hogg, 1998). However, such opportunities are usually optional, and additional to the final-year dissertation, rather than as an alternative to it.

Electrical Engineering students at Texas A\&M University, who design robots for their capstone project, benefit from the experience of mentoring local high-school students in robotics competitions as part of their capstone project work (Talley, 1997). This links the University to school education in a very practical way. Similarly, Kostelnick et al. (2009) integrate students into Geographical Information System (GIS) projects with a range of communities from the academic to the civic.

Team-based problem-solving is used in the final-year capstone course at the University of Queensland's Faculty of Natural Resources, Agriculture and Veterinary Science, to give students the experience of research-based consultancy. An interdisciplinary staff 
team solicits suitable 'problems' and clients among their contacts, including government agencies, non-governmental organizations, land-care groups and the private sector. The clients attend an initial briefing with their student 'consultants', watch presentations at the end of the first and second semesters and receive the final reports. They liaise with the students throughout the year, usually by phone and email. A flexible programme of lectures in the first semester provides the students with the skills they need to perform their tasks (Healey \& Jenkins, 2009a).

There are a variety of ways in which this approach could be embedded into geography programmes. At Bournemouth University, for example, Shah and Treby (2006) describe a community-based project that gives geography students the chance to collaborate on live research activities and work placements. At Liverpool John Moores University, a small number of geography and earth science students submit a report concerning their work-based learning experience rather than producing a traditional dissertation. A survey of geography departments in the UK (Nicholson et al., 2010) indicates that several institutions have the facility for dissertations to be built around work placements and work-based activities, but that few students opt for this route.

Whether these projects are solo or team-based depends on the circumstances. Three significant advantages of undertaking team projects in the community are that more complex issues can be tackled, more individuals can be involved and safety matters concerning lone working can be ameliorated. Group working does, however, have implications for assessment (Table 2) and, as with all group projects, group dynamics can have a significant influence on outcomes if not carefully managed.

Vertical projects-involving students from different years. At Glasgow Caledonian University, the School of the Built and Natural Environment offers a Vertical Project in which first-, second- and third-year students collaborate on a project in small groups. Students gradually progress from completing allocated tasks in Year 1, such as data collection, to taking on leadership and project management roles in Year 3 (Pahl, 2008). Thus, students are gradually integrated into the research process and into the community of practice of their subject. Similarly, Civil Engineering at Rhode Island University runs a design experience with undergraduate students from different years playing different roles (McEwen, 1994). This approach provides students with opportunities to work on current problems with practising engineers and groups of colleagues in a way that mirrors the professional design office.

In an interesting variation on this theme, Chang (2005) uses knowledge from one cohort and passes it to students in succeeding years; "each year students receive a body of work produced by the previous group of students and make improvements and additions to it; this process can be repeated until publishable materials are produced" (Chang, 2005, p. 387). The University of Leeds Innocence Project for volunteer law students combines both approaches, involving students passing to subsequent cohorts case histories of those claiming wrongful imprisonment (McCartney, 2006).

Proposals to operationalize opportunities in these styles are likely to meet pragmatic opposition based on practicalities in timetabling, but they do present interesting role models for growing and deepening understanding. Similar initiatives would have educational benefits through making students aware of other disciplinary concerns and real-world issues, as well as providing opportunities for developing mentoring skills. 
Table 2. Assessment criteria for Honours dissertations (based on Hand \& Clewes, 2000; Nicholson et al., 2010)

\author{
Fundamentals of the dissertation \\ - Evidence of originality and perceptiveness \\ - Clarity of aims and topic identification \\ - Evidence of reading and awareness of literature \\ - Quality of research design and methodology \\ - Awareness of any shortcomings of design and methodology \\ - Quality of data \\ - Presentation, analysis, evaluation, synthesis and interpretation of data \\ - Conceptual awareness and theoretical understanding \\ - Sustained argument \\ - Logical organization \\ - Findings and conclusions justified and contextualized in the literature \\ - Where appropriate, improvements or further developments of study \\ Presentation \\ - Standard of presentation, use of English language and structure \\ - Use of complex academic terminology \\ - Correct use of referencing conventions \\ - Coherent integration of illustrative materials \\ Administrative \\ - Conduct including engagement with administrative processes \\ - Assessment of risks and ethical considerations \\ - Compliance with requirements \\ Independence \\ - Ability to work independently \\ - Exercise of personal initiative and responsibility \\ - Conduct and competence during practical work \\ - Cognitive, intellectual, practical and personal skills \\ - Appropriate and correct use of ICT applications \\ - Reflective, critically evaluating own performance and personal development \\ The 'X Factor' \\ - Demonstrable critical ability \\ - Creative thinking \\ - Flair and innovation
}

Creative forms - art and design, photography and video, online technologies. There is potential for capstone projects in which a creative 'product' is presented alongside some form of critical commentary or narrative, an approach that is common in the creative disciplines. The BA (Hons) Fashion, Design and Technology at Manchester Metropolitan University includes a 40-credit Major Project, where students design, make and show a 30-piece garment collection, in association with a 20-credit Personal Monograph. The monograph is amply illustrated with photographs taken at every stage in the process and provides: a formative Statement of Intent for the Major Project; a summative, critical and highly reflective commentary and justification of the design process and influences upon it; the development of design ideas including the making of garments; and an evaluation of complex technical processes. As a demonstration of advanced independent research work linking to underpinning theory and published sources, the monograph has the look and feel of a traditional Honours project. Moreover, the monograph provides a commentary on a body of creative work completed in a separate major project, thereby making explicit links between modules. 
McGrann et al. (2005) discuss the process of connecting engineering and design students in a capstone project at Binghamton University, New York, to create an outdoor sculpture to be placed at the entrance of the Discovery Centre in the city. The authors highlight the opportunities and challenges afforded through working in multi-disciplinary teams. These include developing an effective dialogue using a language understood by all participants, appreciating and fulfilling professional responsibilities, and maintaining motivation across all participating students in order to successfully meet aggressive deadlines.

As a discipline, geography also offers a variety of opportunities for students to develop and apply creative skills to real-world issues. Examples include environmental design, urban regeneration planning, cartography and GIS, environmental and landscape art, and landscape interpretation.

Assessment of a level three urban geography fieldwork course in Geography, University of Southampton, is based on the use of digital photography and the creation of group websites by teams of students (Latham \& McCormack, 2007). While in the field, in addition to notetaking, students also use diagrams, sketches, digital photographs and video material to record their impressions, which are then built into their websites.

The Geography Department of the National University of Ireland, Maynooth, has adapted a previously successful distance-learning approach to support final-year dissertation students through online supervision (MacKeogh, 2006). Students contribute to discussion fora, submit individual research proposals, and discuss and critique other proposals. Assessment is on the basis of online participation, literature review, an action plan, a reflective diary and completion of a research ethics form. Subsequently, students collect data and prepare their report and presentation, supporting each other using the online fora.

Products such as these will always need to be accompanied by critical, evaluative and reflective commentary. There may also be technical and logistical issues for some types of project, institutions and individuals. Nevertheless, these examples encourage thinking about creative ways of representing geographical knowledge.

Mapping products and visualization. Effective mapping and data visualization are fundamental to the 'business of geography', and making a creative mapping product is a wholly appropriate outcome for a geography capstone project. Mapping may seem initially to be a simple display process, but it has the potential to be as highly creative as the products referred to in Section 'Creative forms-art and design, photography and video, online technologies' (Table 1). Assessment processes based on field notebooks, draft and final mapping products are already available in GIS degree programmes. Whitmeyer et al. (2008) link geology and engineering students from two institutions for a field mapping project: "this experiment in cross-disciplinary undergraduate research was a big success, ... enthusiastic interchange of expertise between undergraduate geology and engineering students ... produced new, cutting-edge methods for visualizing geologic data and maps." Swanson and Bampton (2009) report on a programme linking undergraduates with academics to map the geology of the Maine coast. Eight weeks of mapping gives students field, GIS and digital mapping experience. The outcomes are presented as posters at the Northeast Geological Society of America Conference, giving the students an insight into academic research culture. 


\section{Changing Product?}

The undergraduate research project in the UK and Ireland generally culminates in a written dissertation that is read only by the student, the supervisor and the second marker (Harrison \& Whalley, 2008). In contrast, the concept of radical collegiality encourages widespread communication, with students informing each other and their faculty of their research findings. There are opportunities to rethink the format of research dissemination to integrate students into research communities. These include, for example, interim posters and/or oral presentations of research work, final-year conference presentations and research journals. Dissemination could also extend to professional audiences via presentations and displays.

A number of creative examples of alternative products can be found in the USA, both within and beyond the boundaries of the discipline. Troyer (1993), for example, offers a template for a metacognitive portfolio of students' work discussing their intellectual development as college students; Elliott et al. (1998) introduce an 'active-learning' project in which senior economics majors research topics linking works of distinguished economists; and Hovorka (2009) describes a classroom-based geography capstone course that explores 10 key geographic ideas. Course assignments include a group presentation in which students argue why a chosen geographic idea stands as the most significant one for the discipline and the 'real world'; a portfolio of personal reflections on the evolution of geographic ideas and how their knowledge of these ideas will serve them in the future; and a paper reflecting on a pivotal idea encountered during undergraduate studies and how this idea changed their perspective on the world.

At Alaska Pacific University, students in all disciplines present their capstone project research as a professional public presentation to faculty, students and the members of the public. Other classes are cancelled so that the student body may attend. The final assessment takes account of a 40-60-page research paper, the quality of the presentation and the handling of questions. While numbers of graduating students are small (approximately 70 per year), the idea of a public presentation as part of the final-year project could be adapted by larger departments and institutions (Healey \& Jenkins, 2009a).

There are some examples of assessment diversity already. The MA Academic Practice students at Manchester Metropolitan University can choose whether the 60-credit (600 hour) project is assessed by a 8000-10 000-word dissertation, published papers or an Equivalent Product. The Equivalent Product, echoing Style 7 (Table 1), may involve an artefact such as CD or DVD, film, boxed game or other physical output, a recording of a performance, an event or a teaching resource (e.g. reusable learning object, web-based learning module or resource). Students seek approval of their product idea during the formative project proposal stage. The product is accompanied by a written commentary that must include an abstract, a rationale for the work, aims, a research methodology if appropriate, a reference list and conclusions.

At the University of Kent, final-year bioscience students can take a Science Communication project, which involves writing a 6000-word report on a controversial or poorly understood area of science (Lloyd, 2008). The students make an assessed oral presentation on their chosen issue in a local school and prepare a magazine article, museum display or website communicating the research issue to a wider public. This style of activity would be highly relevant for students seeking a teaching career. 
Most of the 'product' options presented would require the application of skills that are already provided and developed elsewhere within a geography programme. These might reasonably include skills in fieldwork, GIS and digital mapping, together with generic employability skills such as group working, Information and Communication Technologies (ICT), oral presentations and posters. However, successful adoption of alternative, creative and innovative approaches to geography dissertations may require some additional skills development and preparation. For instance, students may need training in the peer-review process for submission to a student journal; practice in collaborative enquiry in multidisciplinary groups; the development of digital photographic or video-editing skills; development of entrepreneurial skills; and training in approaches to mentoring. In addition, there may be a need for a departmental or institutional change of mindset that facilitates collaboration with academic and research communities and increases administrative flexibility within modularized programmes.

\section{Changing Assessment?}

The capstone project can represent a significant component of the degree assessment; up to one-third of final-year marks in the UK (Nicholson et al., 2010). Summative assessment typically combines a number of elements including interim or progress reports, interim or final presentations and the written report (Harrison \& Whalley, 2008), with the written element accounting for 70-100 per cent (Nicholson et al., 2010). Some of the options for capstone products highlighted above would require more than a single output and considerable care would need to be taken to ensure appropriate output weighting and the application of consistent criteria within cohorts.

In the UK and Ireland, capstone projects are generally marked by two people. In departments with cohorts of 200 or more final-year students, this can involve 30 or more assessors, making consistency of assessment between markers challenging (Saunders \& Davis, 1998; Webster et al., 2000; Pepper et al., 2001). Inter-marker variability is ameliorated through the use of carefully designed assessment criteria, alongside clear marking procedures, that are debated and revised periodically (Saunders \& Davis, 1998; Pathirage et al., 2007). The use of benchmark statements as a foundation for the development of assessment criteria ensures some degree of consistency in standards across the HE sector, but there is considerable variation in approaches to developing criteria at a local level (Nicholson et al., 2010). Methods include teaching team discussions, working parties, formal review, consultation with external examiners and evolution through time as a product of shared experience and tradition. Assessment criteria for geography dissertations may be discipline specific or generic, having been developed at the institutional level. There is much commonality in assessment criteria across disciplines, including, for example, biological sciences Honours projects (Stefani et al., 1997), social sciences including geography (Webster et al., 2000; Pepper et al., 2001), business and history (Hand \& Clewes, 2000; Woolf, 2004). The data in Table 2 summarize the attributes and skills frequently occurring in learning outcomes and marking criteria for dissertations (Hand \& Clewes, 2000; Nicholson et al., 2010). Skills derived from team working and effective collaboration are conspicuously absent.

Woolf (2004), considering assessment criteria for final-year Honours projects in business and history programmes, noted the need for improved shared understanding by staff and students of the language used in criteria and the ways in which criteria are applied 
in marking. In a similar study of dissertation assessment in social sciences and law, Webster et al. (2000) revealed considerable ambiguity over the meaning and application of criteria among academic staff. The central role of Honours dissertations and significant contribution towards the final-year marks (Nicholson et al., 2010) makes effective implementation of assessment criteria particularly important (Pepper et al., 2001). For 'unconventional' dissertations, it becomes even more important to reach agreement on treatment (Webster et al., 2000).

Broadening the style of projects will inevitably give rise to new challenges for fair and objective assessment, which may present difficulties with rigorous application of criteria (Table 2). Pathirage et al. (2007) highlight the apparent autonomy versus accountability dichotomy between work that is intended to represent individuality and creativity, against the necessity to implement assessment criteria—referred to as 'straight-jacketing' by Balla and Boyle (1994).

Arguably, these issues are already addressed in other disciplines, engineering and the creative arts in particular. Adopting procedures used in departments elsewhere in a university can obviate challenges about comparability and university standards. Assessment criteria will need to cater for the differences inherent in independent versus collaborative constructions of knowledge and in the differing levels of student engagement with the research process. Students working in research groups, with support from research fellows and professors, should be expected to work at a more advanced and deep level than entirely student collaborative groups and this will need to be reflected in assessment criteria. Where students are co-researching with supervisors, co-publishing and copresenting, peer review of student articles, as a measure of assessment, could be formalized. Assessment criteria will also need to cater for increased variety in the nature of the capstone product to ensure consistency of standards and appropriate rewarding of student effort and achievement. Consistent assessment criteria could be developed for both undergraduate and taught postgraduate levels to clarify both criteria and the 'higher postgraduate' standards or demands of a dissertation submitted at the more advanced level. Students should be able to see the 'step up' to M level and rise to the challenge. Consistency across institutions will continue to be an issue, but in terms of the development of research skills, these could be included in the assessment process through a recognized Research Skills Development Framework (see Willison \& O'Regan, 2007). The examples given from many disciplines reviewed above indicate the acceptability of alternatives to the traditional format.

\section{Conclusions}

Ideally a final-year research project should inspire and challenge a student to think in new ways, to apply their expertise to explore and solve problems, and to share that thinking and new experience with peers. Currently, geography dissertations in UK and Irish Higher Education Institutions (HEIs) largely constrain students to a particular process and product. We argue for broadening the format to challenge students to demonstrate their higher-order cognitive, affective and inter-personal learning skills in ways that align with their ambitions and interests (agreeing with Healey, 2010). For students who anticipate a research career, the traditional dissertation is appropriate, but could be an enhanced experience, where the student works with an active research group or produces a researchrelevant product. Students seeking careers outside the Academy should be able to opt for 
projects that develop their understanding of workplace, charity or professional sectors, as well as developing the critical thinking, synthesis and evaluation skills that are central to all research projects. These approaches should enable students to become active participants in either academic or business and commercial communities of practice, countering Lave and Wenger's (1991) and Wenger's (1998) view that the sense of community is missing from the general student experience. More challenging is the concept of the capstone project emerging from collaborative research across years, disciplines and institutions, and the creation of student-student and student-faculty communities of practice.

Changing the format of the dissertation has implications across the curriculum. Collaborative research ideas, protocols and etiquettes would need thought and introduction from Year 1. But the benefits for research outputs, personal development and profiles are potentially huge. Where Year 1 students join academic research teams, faculty may more easily see students as young members of departments and disciplines. It could encourage mentoring to be facilitated across the student years and help to develop effective team working and writing skills. This model has the potential to work well in applied projects undertaken with external stakeholders to develop outputs that offer real impact, and build stable, long-term academy-industry links. The Business Plan capstone project already exists in some enterprise and business programmes, but it could be more widely adopted. For students intent on starting their own business, it provides an opportunity to focus on business processes, and to research and evaluate options in depth.

We recognize that any capstone product must engage students in academic or professional writing, synthesis, analysis and evaluation, and provide opportunities to develop and demonstrate creativity at an appropriate level. The contention here is that products that facilitate student work within communities of practice provide an experience of the reality of research in the Academy and the real world, which is predominantly team centred and collaborative. The ambition is for comprehensive and robust capstone learning experiences that more closely relate to processes of both knowledge creation and knowledge dissemination in the disciplines and professions. However, barriers that potentially inhibit the delivery of more creative, research-oriented capstone experiences include curriculum constructions, insufficient faculty resource allocation, static institutional values and culture, inadequate supporting infrastructure and ethical considerations. Thus, good practice must be both defined and managed appropriately, along with a desirable end state, such that newly evolved research experiences engage students in academic communities of practice and dissemination. Students should be empowered as active agents in the research process and not be alienated to independent research anchored by isolated meetings with supervisors.

Re-imagining capstone projects relies on supervisor development and shared practice, sometimes lacking in institutions (Rowley \& Slack, 2004). Students must be offered opportunities to reflect upon and report their experiences, thereby informing curriculum development. A positive outcome could be a more integrated approach to planning and support for teaching, research and knowledge transfer, which emphasizes their complementary nature. The Honours dissertation should retain its central place in the undergraduate curriculum, but greater diversity could enhance its relevance to students and employers, better aligning the student experience with the academic interests and career aspirations of the 21 st century geography graduate. 


\section{References}

Aller, B. M., Lyth, D. M. \& Mallak, L. A. (2008) Capstone project team formation: Mingling increases performance and motivation, Decision Sciences Journal of Innovation Education, 6, pp. 503-507.

Amin, A. \& Roberts, J. (2008) Knowing in action: Beyond communities of practice, Research Policy, 37, pp. 353-369.

Arnot, M., McIntyre, D., Peddar, D. \& Reay, D. (2004) Consultation in the Classroom: Developing Dialogue about Teaching and Learning (Cambridge: Pearson).

Askins, K. (2008) In and beyond the classroom: Research ethics and participatory pedagogies, Area, 40, pp. 500-509.

Balla, J. \& Boyle, P. (1994) Assessment of student performance: A framework for improving practice, Assessment and Evaluation in Higher Education, 19, pp. 17-28.

Baxter Magolda, M. (1999) Creating Contexts for Learning and Self-authorship: Constructive Developmental Pedagogy (San Francisco, CA: Jossey-Bass).

Baxter Magolda, M. (2009) Educating for self-authorship: Learning partnerships to achieve complex outcomes, in: C. Kreber (Ed.) The University and its Disciplines: Teaching and Learning within and beyond Disciplinary Boundaries, pp. 143-156 (Oxford: Routledge).

Bednarz, S., Chalkley, B., Fletcher, S., Hay, I., Le Heron, E., Mohan, A. \& Trafford, J. (2008) Community engagement for student learning in geography, Journal of Geography in Higher Education, 32, pp. 87-100.

Boud, D., Cohen, R. \& Sampson, J. (1999) Peer learning and assessment, Assessment in Higher Education, 24, pp. $413-426$.

Boyer Commission on Educating Undergraduates in the Research University (1998) Reinventing Undergraduate Education: A Blueprint for America's Research Universities (Stony Brook, NY: State University of New York at Stony Brook).

Brackin, M. P. \& Gibson, J. D. (2005) Capstone design projects with industry: Emphasizing teaming and management tools, ASEE Annual Conference and Exposition, Conference Proceedings, pp. 1477-1484.

Brew, A. (2003) Teaching and research: New relationships and their implications for inquiry-based teaching and learning in higher education, Higher Education Research and Development, 22, pp. 3-18.

Brew, A. (2006) Research and Teaching beyond the Divide (London: Palgrave MacMillan).

Bruhn, R. \& Camp, J. (2004) Capstone course creates useful business products and corporate-ready students, SIGCSE Bulletin (Association for Computing Machinery, Special Interest Group on Computer Science Education), 36, pp. 87-92.

Chalkley, B. \& Gibson, K. (2009) Enterprise education in geography: The case of the Plymouth dragons, Planet, 21, pp. 43-46.

Chalkley, B. \& Harwood, J. (1998) Transferable Skills and Work-based Learning in Geography (Cheltenham: Geography Discipline Network).

Chang, H. (2005) Turning an undergraduate class into a professional research community, Teaching in Higher Education, 10, pp. 387-394.

Charlesworth, S. M. \& Foster, I. D. L. (1996) 'Water and environmental systems': Achieving student-centred learning objectives with an undergraduate journal, Journal of Geography in Higher Education, 20, pp. $45-54$.

Dorsey, B. (2001) Linking theories of service-learning and undergraduate geography education, Journal of Geography, 100, pp. 124-132.

Dougherty, J. \& Parfitt, K. (2009) Framework for teaching engineering capstone design courses with emphasis on application of Internet-based technologies, Journal of Architectural Engineering, 15, pp. 4-9.

Dutson, A. J., Todd, R. H., Magleby, S. P. \& Sorenson, C. D. (1997) A review of literature on teaching engineering design through project-oriented capstone courses, Journal of Engineering Education, 86, pp. 17-28.

Elliott, D., Meisel, J. \& Richards, W. (1998) The senior project: Using the literature of distinguished economists, Journal of Economic Education, 29, pp. 312-320.

Fielding, M. (1999) Radical collegiality: Affirming teaching as an inclusive professional practice, Australian Educational Researcher, 26, pp. 1-34.

Fielding, M. (2001) Students as radical agents of change, Journal of Educational Change, 2, pp. 123-141.

Fielding, M. (2004) Transformative approaches to student voice: Theoretical underpinnings, recalcitrant realities, British Educational Research Journal, 30, pp. 295-311.

Fisher, C. (2007) Researching and Writing a Dissertation: A Guidebook for Business Students, 2nd edn (Harlow: Pearson Education Ltd). 
Gemmel, A. (1995) 'Competitive' simulation in the teaching of applied geomorphology: An experiment, Journal of Geography in Higher Education, 19, pp. 29-39.

Gemstone (2010) The Gemstone Program at the University of Maryland. Available at http://www.gemstone.umd. edu/about/index.html (accessed 1 July 2010).

Greenbank, P. \& Penketh, C. (2009) Student autonomy and reflections on researching and writing the undergraduate dissertation, Journal of Further and Higher Education, 33, pp. 463-472.

Hadfield, M. \& Hawe, K. (2001) 'Voice', young people and action research, Educational Action Research, 9, pp. 85-99.

Haigh, M. J. (2002) Internationalisation of the curriculum: Designing inclusive education for a small world, Journal of Geography in Higher Education, 26, pp. 49-66.

Hand, L. \& Clewes, D. (2000) Marking the difference: An investigation of the criteria used for assessing undergraduate dissertations in a business school, Assessment and Evaluation in Higher Education, 25, pp. $5-21$.

Harrison, M. E. \& Whalley, W. B. (2008) Undertaking a dissertation from start to finish: The process and product, Journal of Geography in Higher Education, 32, pp. 401-418.

Harvey, L., Moon, S. \& Geall, V. (1997) Graduates' Work: Organisational Change and Student Attributes (Birmingham: Centre for Research into Quality, University of Birmingham).

Healey, M. (2010) Making creative-hops through developing creative honours projects: A proposal. Paper presented at the SRHE Student Experience Conference on Rethinking the Dissertation: The Role of Undergraduate Research in Higher Education. UCLan, Preston, 9 June.

Healey, M. \& Jenkins, A. (2009a) Developing Undergraduate Research and Inquiry (York: HE Academy).

Healey, M. \& Jenkins, A. (2009b) Developing students as researchers, in: S. K. Haslett \& H. Rolands (Eds) Linking Research and Teaching and in Higher Education. Proceedings of the Newport Nexus Conference. Centre for Excellence in Learning and Teaching, University of Wales, Wales. Special Publication No. 1, pp. $7-11$.

Hennemann, S. \& Liefner, I. (2010) Employability of German geography graduates: The mismatch between knowledge acquired and competences required, Journal of Geography in Higher Education, 34, pp. $215-230$.

Higgitt, D. (2006) Finding space for education for sustainable development in the enterprise economy, Journal of Geography in Higher Education, 30, pp. 251-262.

Hodgson, D., May, S. \& Marks-Maran, D. (2008) Promoting the development of a supportive learning environment through action research from the 'middle out', Educational Action Research, 16, pp. 531-544.

Hogg, J. (1998) Evaluation of the work-place cooperative project in geography degrees at the University of Leeds, Journal of Geography in Higher Education, 22, pp. 126-135.

Hovorka, A. J. (2009) A capstone course of 'geographic ideas', Journal of Geography, 108, pp. 252-258.

James, P. (1998) Progressive development of deep learning skills through undergraduate and postgraduate dissertations, Educational Studies, 24, pp. 95-105.

Jenkins, A. (2003) Designing a curriculum that values a research based approach to student learning in geography, earth and environmental sciences (GEES), Planet, Special Edition 5, pp. 2-5.

Jenkins, A., Blackman, T., Lindsay, R. \& Paton-Saltzberg, R. (1998) Teaching and research: Student perspectives and policy implications, Studies in Higher Education, 23, pp. 127-141.

Jenkins, A., Breen, R. \& Lindsay, R. (2003) Re-shaping Higher Education: Linking Teaching and Research (London: Routledge).

Jenkins, A. \& Healey, M. (2010) Undergraduate research and international initiatives to link teaching and research, Council on Undergraduate Research Quarterly, 30, pp. 36-42.

Jenkins, A., Healey, M. \& Zetter, R. (2007) Linking Teaching and Research in Disciplines and Departments (York: Higher Education Academy).

Kostelnick, J. C., Rowley, R. J., McDermott, D. \& Bowen, C. (2009) Developing a GIS program at a tribal college, Journal of Geography, 108, pp. 68-77.

Latham, A. \& McCormack, D. (2007) Digital photography and web-based assignments in an urban field course: Snapshots from Berlin, Journal of Geography in Higher Education, 31, pp. 241-256.

Lave, J. \& Wenger, E. (1991) Situated Learning: Legitimate Peripheral Participation (Cambridge: Cambridge University Press).

Le Heron, R., Baker, R. \& McEwen, L. (2006) Co-learning: Re-linking research and teaching geography, Journal of Geography in Higher Education, 30(1), pp. 77-87. 
Leidig, P. M., Ferguson, R. \& Leidig, J. (2006) The use of community-based non-profit organizations in information systems capstone projects, Working Group Reports on ITiCSE on Innovation and Technology in Computer Science Education, 11th Annual Joint Conference Integrating Technology into Computer Science Education, Università di Bologna, Bologna, Italy. pp. 148-152.

Lloyd, D. (2008) Final year research projects in communicating science, in: M. Luck (Ed.) Student Research Projects: Guidance on Practice in the Biosciences, Teaching Bioscience Enhancing Learning Series (Leeds: The Higher Education Academy Centre for Bioscience), pp. 54-56.

Lynch, K., Bednarz, B., Boxall, J., Chalmers, L., France, D. \& Kesby, J. (2008) E-learning for geography's teaching and learning spaces, Journal of Geography in Higher Education, 32, pp. 135-149.

Lynch, K., Heinze, A. \& Scott, E. (2007) Information technology team projects in higher education: An international viewpoint, Journal of Information Technology Education, 6, pp. 181-198.

MacKeogh, K. (2006) Supervising undergraduate research using online and peer supervision, in: M. Huba (Ed.) Proceedings of the 7th International Virtual University Conference, 14-15 December 2006, Bratislava. TU Bratislava. Available at http://doras.dcu.ie/82/ (accessed 1 July 2010).

McCartney, C. (2006) The University of Leeds Innocence Project. Available at http://www.law.leeds.ac.uk/pro spective-students/undergraduates/extra/innocence-project.php (accessed 1 July 2010).

McEwen, E. E. (1994) Integrated capstone design experience, Journal of Professional Issues in Engineering Education and Practice, 120, pp. 212-220.

McGrann, R., Mackiewicz, G., Walsh, J., Williams, K., Griffin, J., Hobbs, Y. \& Crocker, M. (2005) Capstone design: Sculpture and structure, ASEE Annual Conference and Exposition, Conference Proceedings, Portland, Oregon. pp. 1485-1491.

Maleki, R. A. (2009) Business and industry project-based capstone courses: A reflection on the performance of student teams, Industry and Higher Education, 23, pp. 103-110.

Nicholson, D. T. (in press) Embedding research in a field-based module through peer review and assessment for learning, Journal of Geography in Higher Education. DOI: 10.1080/03098265.2011.552104.

Nicholson, D. T., Harrison, M. E. \& Whalley, W. B. (2010) Assessment criteria and standards of the Geography Dissertation in the UK, Planet, 23, pp. 18-24.

Oldfather, P. (1995) Songs 'come back to most of them': Students' experiences as researchers, Theory into Practice, 34, pp. 131-137.

Pahl, O. (2008) Case study 8: The Vertical Project, Glasgow Caledonian University, in: F. M. Black \& J. MacKenzie (Eds) Quality Enhancement Themes: The First Year Experience, pp. 43-45 (Glasgow: Quality Assurance Agency for Higher Education).

Pathirage, C., Haigh, R., Amaratunga, D. \& Baldry, D. (2007) Enhancing the quality and consistency of undergraduate dissertation assessment, Quality Assurance in Education, 15, pp. 271-286.

Pepper, D., Webster, F. \& Jenkins, A. (2001) Benchmarking in geography: Some implications for assessing the dissertations in the undergraduate curriculum, Journal of Geography in Higher Education, 25, pp. 23-35.

QAA (2007) Geography, and Earth Sciences, Environmental Sciences and Environmental Studies Benchmark Statement (Gloucester: Quality Assurance Agency).

Rohleder, P., Swartz, L., Bozalek, V., Carolissen, R. \& Leibowitz, B. (2008) Community, self and identity: Participatory action research and the creation of a virtual community across two South African universities, Teaching in Higher Education, 13, pp. 131-143.

Rowles, C. J., Koch, D. C., Hundley, S. P. \& Hamilton, S. J. (2004) Towards a model for capstone experiences: Mountaintops, magnets and mandates, Assessment Update: Progress, Trends and Practices in Higher Education, 16, pp. 1-2 and 13-15.

Rowley, J. \& Slack, F. (2004) What is the future for undergraduate dissertations? Education and Training, 46, pp. $176-181$.

Saunders, M. N. K. \& Davis, S. M. (1998) The use of assessment criteria to ensure consistency of marking: Some implications for good practice, Quality Assurance in Education, 6, pp. 162-171.

Shah, A. \& Treby, E. (2006) Using a community based project to link teaching and research: The bourne stream partnership, Journal of Geography in Higher Education, 30, pp. 33-48.

Simplicio, S. C. (2007) Educating the 21st Century Student (Bloomington: AuthorHouse).

Stefani, L. A., Tariq, V. N., Heylings, D. J. A. \& Butcher, A. C. (1997) A comparison of tutor and student conceptions of undergraduate research project work, Assessment and Evaluation in Higher Education, 22, pp. $271-288$.

Swanson, M. T. \& Bampton, M. (2009) Integrated digital mapping in geologic field research: An adventure-based approach to teaching new geospatial technologies in an REU Site Program, in: S. J. Whitmeyer, D. W. Mogk, 
and E. J. Pyle (Eds.) Field Geology Education: Historical Perspectives and Modern Approaches: Geological Society of America Special Paper 461, pp. 117-133.

Talley, T. J. (1997) Using a state-wide high school robotics competition as the basis for a capstone design experience in electrical engineering, Proceedings-Frontiers in Education Conference, 2, pp. 775-777.

Tatner, M. \& Tierney, A. (2008) Case study 6: Commercial projects for final year bioscience students, in: M. Luck (Ed.) Student Research Projects: Guidance on Practice in the Biosciences, pp. 51-53 (Leeds: HEA Subject Centre for Bioscience).

Terenzini, P. T. \& Pascarella, E. T. (1998) Studying college students in the 21st century: Meeting new challenges, The Review of Higher Education, 21, pp. 151-165.

Tilley, F. \& Parrish, B. D. (2009) Introduction to sustainability entrepreneurship research, Greener Management International, 55, pp. 5-11.

Troyer, R. J. (1993) Comments on the capstone course, Teaching Sociology, 21, pp. 246-249.

Turner, N., Wuetherick, B. \& Healey, M. (2008) International perspectives on student perceptions of research: The role of academic development in implementing research-based teaching and learning in higher education, International Journal of Academic Development, 13, pp. 199-211.

Waddington, S. (2001) Working with the community: Improving the learning experience for large classes, Journal of Geography in Higher Education, 25, pp. 67-82.

Wagner, R., Anderson, J. L., Cao, W., Gao, Y., Ikeda, T., Jacobs, R., Johanesen, K., Mai, J., Memeti, V., Padilla, A., Paterson, S. R., Seyum, S., Shimono, S., Thomas, T., Thompson, J. \& Zhang, T. (2007) Geologic wonders of Yosemite at two miles high: An undergraduate, learner-centered, team research program at the University of Southern California, American Geophysical Union, Fall Meeting 2007, abstract \#ED21A-0082. Available at http://adsabs.harvard.edu/abs/2007AGUFMED21A0082W

Walkington, H. (2008) Geoverse: Piloting a national e-journal of undergraduate research in geography, Planet, 20, pp. 41-46.

Walkington, H. \& Jenkins, A. (2008) Embedding undergraduate research publication in the student learning experience: Ten suggested strategies, Brookes E-journal of Learning and Teaching, 2(3). Available at http://bejlt.brookes.ac.uk/article/embedding_undergraduate_research_publication_in_the_student_lear ning_experi/

Wallen, M. R. \& Pandit, A. S. (2009) Encouraging undergraduate engineering students towards civic engagement, European Journal of Engineering Education, 34, pp. 141-148.

Webster, F., Pepper, D. \& Jenkins, A. (2000) Assessing the undergraduate dissertation, Assessment and Evaluation in Higher Education, 25, pp. 71-80.

Wenger, E. (1998) Communities of Practice: Learning, Meaning and Identity (Cambridge: Cambridge University Press).

Whitmeyer, S. J., de Paor, D. G., Nicoletti, J., Rivera, M., Santangelo, B. \& Daniels, J. (2008) Cross-disciplinary undergraduate research: A case study in digital mapping, western Ireland, American Geophysical Union, Fall Meeting 2008, abstract \#ED52A-04. Available at http://adsabs.harvard.edu/abs/2008AGUFMED52A.04W

Willison, J. \& O'Regan, K. (2007) Commonly known, commonly not known, totally unknown: A framework for students becoming researchers, Higher Education Research and Development, 26, pp. 393-409.

Woolf, H. (2004) Assessment criteria: Reflections on current practices, Assessment and Evaluation in Higher Education, 29, pp. 479-493.

Zamorski, B. (2002) Research-led teaching and learning in higher education, Teaching in Higher Education, 7 , pp. 411-427. 